\section{'Buzzer Beater', 'Hoopla', 'Huskymania', and 'Slam Dunk' Rhododendrons}

\author{
Mark H. Brand ${ }^{1}$ and Gustav A.L. Mehlquist ${ }^{2}$ \\ Department of Plant Science, The University of Connecticut, Storrs, \\ CT 06269-4067
}

Additional index words. broadleaf evergreen, Ericaceae, ornamentals, breeding, cold hardiness

Hybrid rhododendrons (Rhododendron L., Ericaceae Juss.) are some of the most popular flowering, broadleaf evergreens, especially in northern locations that have cold, difficult winters. A relatively limited range of flower colors is available in large-leaf rhododendrons that are cold-hardy in locations where temperatures fall below $-28{ }^{\circ} \mathrm{C}$. There is a need for coldhardy cultivars that have flower colors beyond the typical lavender-purple-magenta colors that are disliked by many people (Dirr, 1998). The Univ. of Connecticut rhododendron breeding program was established in 1960 by G.A.L. Mehlquist to broaden the range of flower colors and plant forms available in coldhardy rhododendrons. Four cold-hardy hybrids were released from the breeding program in 1992 and 1993. Previous introductions had flowers that were purple ('Connecticut Yankee'), red ('Firestorm'), white with a dark blotch ('White Peter'), or plum-purple with a dark blotch ('Wojnar's Purple') (Brand and Mehlquist, 1992, 1993).

Four additional Rhododendron cultivars named 'Buzzer Beater', 'Hoopla', 'Huskymania', and 'Slam Dunk' were released as part of the "Raise the Roof" series of rhododendrons. These cultivars were given basketballrelated names in celebration of recent women's and men's National Collegiate Athletic Association (NCAA) basketball championships in 1995 and 1999. Growers favored the names because they believed plants with basketballrelated names could be marketed more easily.

\section{Origin}

The pedigree for 'Buzzer Beater' is illustrated in Fig. 1. In 1965, a cold-hardy $\left(-32^{\circ} \mathrm{C}\right)$ white-flowered female parent $[R$. catawbiense Michx. var. album Glass 'Catalgla' $\mathrm{F}_{3}$ ] was crossed with a less coldhardy $\left(-20^{\circ} \mathrm{C}\right)$ straw yellow-flowered male parent $[R$. degronianum Carr. sp. yakushi-

Received for publication 6 Mar. 2000. Accepted for publication 1 June 2000. Storrs Agricultural Experiment Station scientific contribution no. 1944. The cost of publishing this paper was defrayed in part by the payment of page charges. Under postal regulations, this paper therefore must be hereby marked advertisement solely to indicate this fact.

${ }^{1}$ Associate Professor, Ornamental Horticulture. Email address: Mark.Brand@uconn.edu

${ }^{2}$ Professor, Plant Breeding, deceased. manum (Nak.) Hara x 'Jalisco' hybrid]. The expectation was to obtain some seedlings with the cold hardiness of the female parent and the flower color of the male parent.

'Hoopla' resulted from a cross made in 1965 between a cold-hardy $\left(-32^{\circ} \mathrm{C}\right)$ whiteflowered female parent $[R$. catawbiense var. album Glass 'Catalgla' $\mathrm{F}_{3}$ ] and a less hardy $\left(-15^{\circ} \mathrm{C}\right)$ hybrid male parent with large pink and yellow flowers [R. haematodes Franch. $\mathrm{x}$ $R$. decorum Franch.]. Again, the breeding goal here was to retain the cold-hardiness of the female parent and the flower color and substance of the male parent. The pedigree for 'Hoopla' is illustrated in Fig. 2.

'Huskymania' was grown from openpollinated seed collected in 1963 (Fig 3.) The seed parent ['Purpureum Grandiflorum'] is a standard purple-flowered cultivar in the nursery industry that possesses medium purple flowers and reasonable cold hardiness $\left(-29{ }^{\circ} \mathrm{C}\right)$. The objective was to obtain offspring with deep purple or blue-purple flowers and equivalent or enhanced cold-hardiness. In fact, the majority of seedlings exhibited purple flowers. The previously introduced 'Connecticut Yankee' was also derived from this cross (Brand and Mehlquist, 1993).

The pedigree for 'Slam Dunk' is illustrated in Fig. 4. The male parent ['Sefton'] of this hybrid has large maroon flowers and is coldhardy to $-29^{\circ} \mathrm{C}$. Unfortunately, it also has a spreading, straggly growth habit. The whiteflowered female parent ['Boule de Neige' seedling] chosen for this cross exhibits a dense, compact growth habit and good cold hardiness. The objective was to combine dense, compact growth habit with large maroon flowers. This cross was made in 1965.

Initial evaluations were conducted over a period of about 15 years. All crosses were made by G.A.L. Mehlquist. These evaluations were conducted at two different Dept. of Plant Science Research Farms in Mansfield, Conn., located in hardiness zone 5 (U.S. Dept. of Agriculture, 1990). Additional evaluations were made in Granby, Conn., North Kingston, R.I., and Hopkinton, Mass. Final selections were made by M.B. and were based on 8 years of evaluation at the main Dept. of Plant Science Research Farms in Mansfield, Conn. Evaluations primarily considered plant habit, foliage quality, winter cold tolerance, disease and insect resistance, quantity of flowers, flower color, and flower substance.

The cultivar names 'Buzzer Beater', 'Hoopla', 'Huskymania', and 'SlamDunk' were

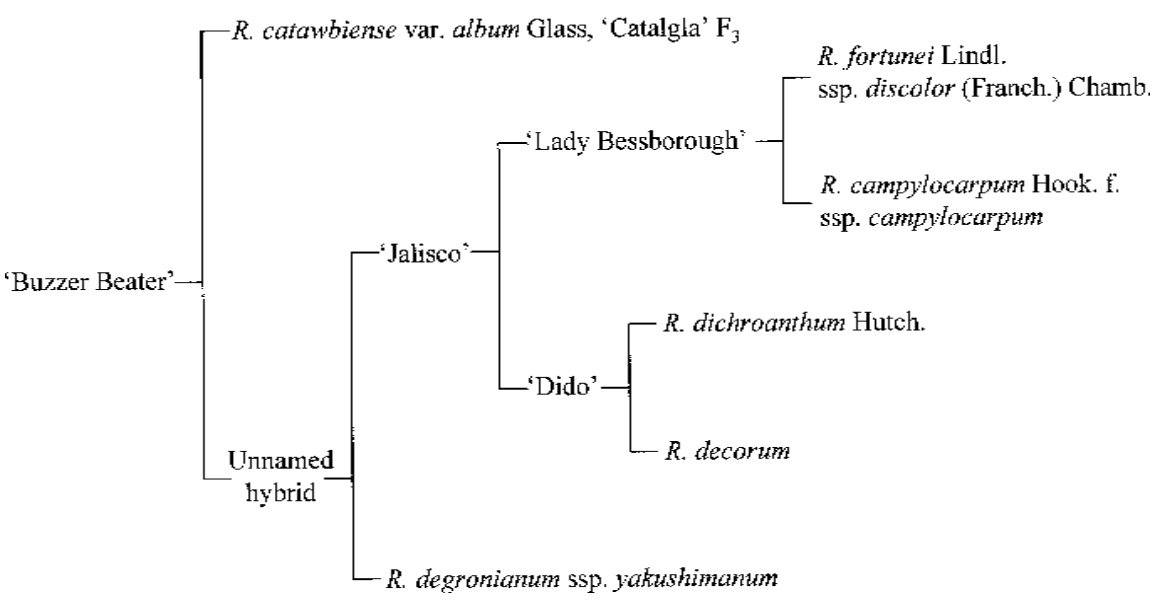

Fig. 1. Pedigree of Rhododendron 'Buzzer Beater'. Female parents are on the upper branches of the tree.

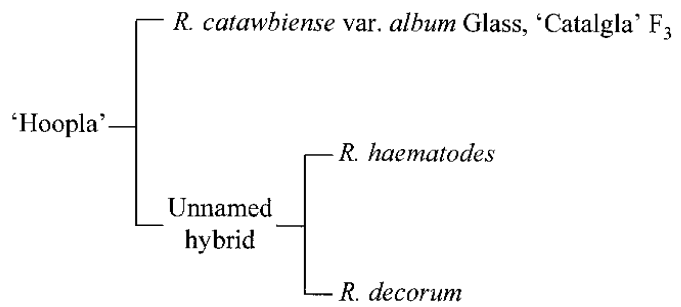

Fig. 2. Pedigree of Rhododendron 'Hoopla'. Female parents are on the upper branches of the tree. 


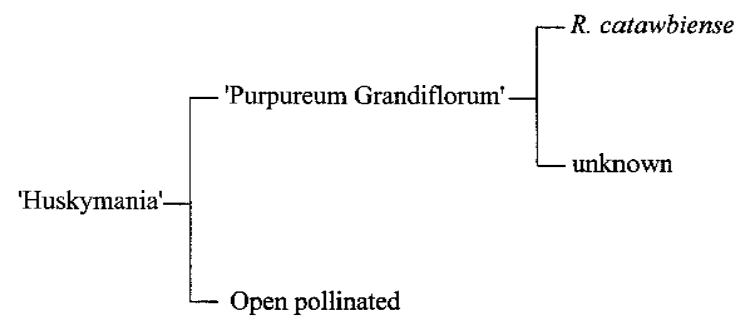

Fig. 3. Pedigree of Rhododendron 'Huskymania'. Female parents are on the upper branches of the tree.

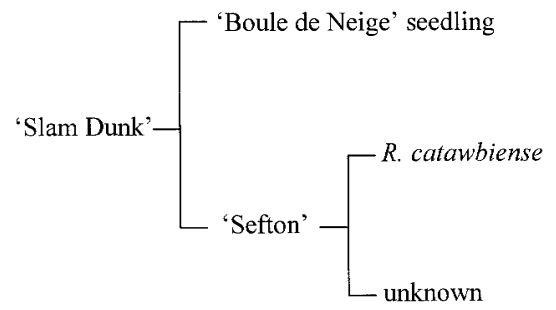

Fig. 4. Pedigree of Rhododendron 'Slam Dunk'. Female parents are on the upper branches of the tree.
Table 1. CIELAB values and calculated hue angles and chroma for flower buds, petal lobes, flower blotchs/flares, and leaves of Rhododendron 'Buzzer Beater', 'Hoopla', 'Huskymania', and 'Slam Dunk'.

\begin{tabular}{|c|c|c|c|c|}
\hline CIELAB values & 'Buzzer Beater' & 'Hoopla' & 'Huskymania' & 'Slam Dunk' \\
\hline \multicolumn{5}{|c|}{ Flower bud } \\
\hline $\mathrm{L}^{* \mathrm{z}}$ & 72.1 & 65.6 & 25.7 & 21.6 \\
\hline$a^{* y}$ & 8.6 & 18.6 & 30.5 & 21.5 \\
\hline$b^{* x}$ & 18.8 & -1.7 & -14.6 & -0.1 \\
\hline Hue angle $^{w}$ & 65.3 & 354.7 & 334.5 & 271.0 \\
\hline Chroma $^{v}$ & 20.9 & 18.8 & 33.8 & 21.7 \\
\hline \multicolumn{5}{|c|}{ Petal lobe } \\
\hline $\mathrm{L}^{*}$ & 89.6 & 70.6 & 44.1 & 39.1 \\
\hline$a^{*}$ & 1.6 & 32.3 & 40.6 & 48.8 \\
\hline$b^{*}$ & 16.7 & -4.0 & -22.6 & -8.3 \\
\hline Hue angle & 83.9 & 353.2 & 331.3 & 350.5 \\
\hline Chroma & 16.8 & 32.4 & 46.3 & 49.6 \\
\hline \multicolumn{5}{|c|}{ Blotch/flare } \\
\hline $\mathrm{L}^{*}$ & 66.7 & 82.5 & 56.1 & 24.4 \\
\hline$a^{*}$ & -.6 & 6.4 & 5.5 & 19.7 \\
\hline $\mathrm{b}^{*}$ & 55.4 & 20.2 & 13.7 & -2.0 \\
\hline Hue angle & 95.7 & 74.2 & 68.8 & 319.0 \\
\hline Chroma & 55.7 & 21.4 & 15.4 & 19.9 \\
\hline \multicolumn{5}{|c|}{ Leaves } \\
\hline $\mathrm{L}^{*}$ & 35.3 & 36.0 & 33.9 & 34.1 \\
\hline$a^{*}$ & -10.5 & -9.3 & -8.0 & -10.2 \\
\hline $\mathrm{b}^{*}$ & 11.8 & 14.3 & 9.4 & 13.1 \\
\hline Hue angle & 131.5 & 123.3 & 130.3 & 128.0 \\
\hline Chroma & 15.8 & 17.1 & 12.3 & 16.6 \\
\hline
\end{tabular}

${ }^{2} L^{*}$ is the value of a color and quantifies the lightness or darkness of a color. Larger values represent whiter colors and smaller values darker colors.

${ }^{\mathrm{a}} \mathrm{a} *$ represents the red-green axis.

${ }^{x} \mathrm{~b} *$ represents the yellow-blue axis.

${ }^{\text {wHe }}$ angle was calculated as $\left(\tan ^{-1} \mathrm{~b}^{*} / \mathrm{a}^{*}\right)$.

${ }^{v}$ Chroma was calculated as $\left(\sqrt{ } a^{* 2}+b^{* 2}\right)$ and describes the saturation or vividness of the color. registered in 1998 with the Royal Horticultural Society, the International Registration Authority for Rhododendron, in accordance with the International Code of Nomenclature for Cultivated Plants_-1995 (Brickell, 1995).

\section{Description}

Descriptions of color (e.g., RHS 147A) for all four cultivars are based on comparisons with the Royal Horticultural Society's color chart (Royal Horticultural Society, 1986). International Commission on Illumination $\mathrm{L}^{*} \mathrm{a} * \mathrm{~b} *$ (CIELAB) coordinates were measured with a Minolta CR-200b colorimeter (Minolta, Ramsey, N.J.) to most accurately choose RHS colors. Each RHS color chip was quantified with the Minolta colorimeter and compared with average colorimeter measurements of 10 leaves or flowers. Color differences $\left(\Delta \mathrm{E}^{*}{ }_{\mathrm{ab}}\right)$ between pairs of plant samples and all color chips were computed as $\Delta \mathrm{E}^{*}{ }_{\mathrm{ab}}=\sqrt{ } \Delta \mathrm{L}^{* 2}+\Delta \mathrm{a}{ }^{* 2}$ $+\Delta \mathrm{b}^{* 2}$ (Seve, 1991). Reported RHS colors are those with the smallest $\Delta \mathrm{E}^{*}{ }_{\mathrm{ab}}$ values. Other CIELAB coordinates found in Table 1 were calculated from the $L * a * b *$ values and included hue angle $\left(\tan ^{-1} b^{*} / a^{*}\right)$ and chroma $\left(\sqrt{ } a^{* 2}+b^{* 2}\right)$.

'Buzzer Beater'. Upright, medium to large rhododendron, to $2.6 \mathrm{dm}$ tall $\times 3.7 \mathrm{dm}$ wide after 25 years, and medium dense with branches spreading. Leaves are simple, flat, elliptic, entire, broadly acute, rotund, semi-glossy, medium green (RHS 147A and 139A), 14 to $18 \mathrm{~cm}$ long $\times 4.5$ to $6.5 \mathrm{~cm}$ wide; petioles are 2.5 to 3.8 $\mathrm{cm}$ long. Trusses are dome-shaped, $15 \mathrm{~cm}$ tall $\times$ $20 \mathrm{~cm}$ wide, bearing 16 to 18 flowers; pedicels are 4.5 to $5.7 \mathrm{~cm}$ long. Flower buds are grayorange (RHS 173D) to gray-red (RHS 179D); calyx is yellow-green (RHS 144C), 2 mm long; corollas (Fig. 5a) are open funnel-shaped to broad funnel-shaped, 5 to $6.5 \mathrm{~cm}$ long $\times 6$ to 8 $\mathrm{cm}$ wide, a light lemon yellow (RHS 159B and $159 \mathrm{C})$, lobes 5 with the dorsal lobe bearing a blotch or flare that varies from yellow-green (RHS 153A and 153B) to gray-orange (RHS 173D) to gray-red (RHS 179D).

'Buzzer Beater' exhibits a vigorous growth rate. Leaves are retained for 2 years and lack indumentum. Plants are floriferous, increasing from moderately to very floriferous with increasing sun exposure at the site. Peak flowering usually occurs in late May at Storrs, Conn. The RHS colors did not match the flower bud color well, with the smallest $\Delta \mathrm{E}^{*}{ }_{\mathrm{ab}}=10.4$. The CIELAB values and calculated hue angle and chroma for leaves and flowers are given in Table 1.

'Hoopla'. Upright, medium-sized rhododendron, $2.1 \mathrm{dm}$ tall $\times 3.1 \mathrm{dm}$ wide after 30 years, and medium dense with branches spreading. Leaves are simple, flat, elliptic, entire, broadly acute, rotund, semi-glossy, medium to dark green (RHS 146A and 147A), 12 to $14 \mathrm{~cm}$ long $\times 4$ to $5 \mathrm{~cm}$ wide; petioles are 2.5 to $3 \mathrm{~cm}$ long. Trusses are dome-shaped, $14 \mathrm{~cm}$ tall $\times 15$ to $17 \mathrm{~cm}$ wide, bearing 10 to 12 flowers; pedicels are 3.0 to $3.5 \mathrm{~cm}$ long. Flower buds are grayedpurple (RHS 186D); calyx is greenish with red margin, $3 \mathrm{~mm}$ long; corollas (Figure 5B) are open funnel-shaped to broad funnel-shaped, 4 to $5 \mathrm{~cm}$ long $\times 7 \mathrm{~cm}$ wide, a light red-purple (RHS 62B and 65A), lobes 5 with an undulate wavy margin and corolla throat is orange-white (RHS 159A) and orange (RHS 27A), creating a bicolor effect.

'Hoopla' exhibits a relatively vigorous growth rate. Leaves are retained for 2 years and lack indumentum. Plants are floriferous, increasing from moderately to very floriferous with increasing sun exposure at the site. Peak flowering usually occurs the second week of May at Storrs, Conn. The CIELAB values and calculated hue angle and chroma for leaves and flowers are given in Table 1.

'Huskymania'. Upright, medium-sized rhododendron, $2.4 \mathrm{dm}$ tall $\times 3.1 \mathrm{dm}$ wide after 30 years, and dense with branches broad and spreading. Leaves are simple, elliptic, entire, undulate, revolute, broadly acute, cuneate, semiglossy, dark green (RHS 139A and 147A), 12$13 \mathrm{~cm}$ long $\times 4-5 \mathrm{~cm}$ wide. Trusses are domeshaped, $14 \mathrm{~cm}$ tall $\times 16 \mathrm{~cm}$ wide, bearing $12-16$ flowers. Flower buds are a strong, dark violet (RHS 83A); calyx is light green, $3 \mathrm{~mm}$ long; corollas (Fig. 5C) are broad funnel-shaped, $5 \mathrm{~cm}$ long $\times 7-8 \mathrm{~cm}$ wide, purple (RHS 78A, $78 \mathrm{~B}$ and $77 \mathrm{~A}$ ), lobes 5 with an undulate fringed margin and the dorsal lobe bearing a $1.5 \mathrm{~cm}$ blotch or flare that most closely matches grayed orange (RHS 177D, 177C, and 177B).

'Huskymania' exhibits a relatively vigorous growth rate coupled with a dense habit. Leaves are retained for 3 years and emerge with nonpersistent, rust-colored indumentum. Plants are floriferous, increasing from moderately to very floriferous with increasing sun exposure at the site. Peak flowering usually occurs in midJune at Storrs, Conn. The CIELAB values and 


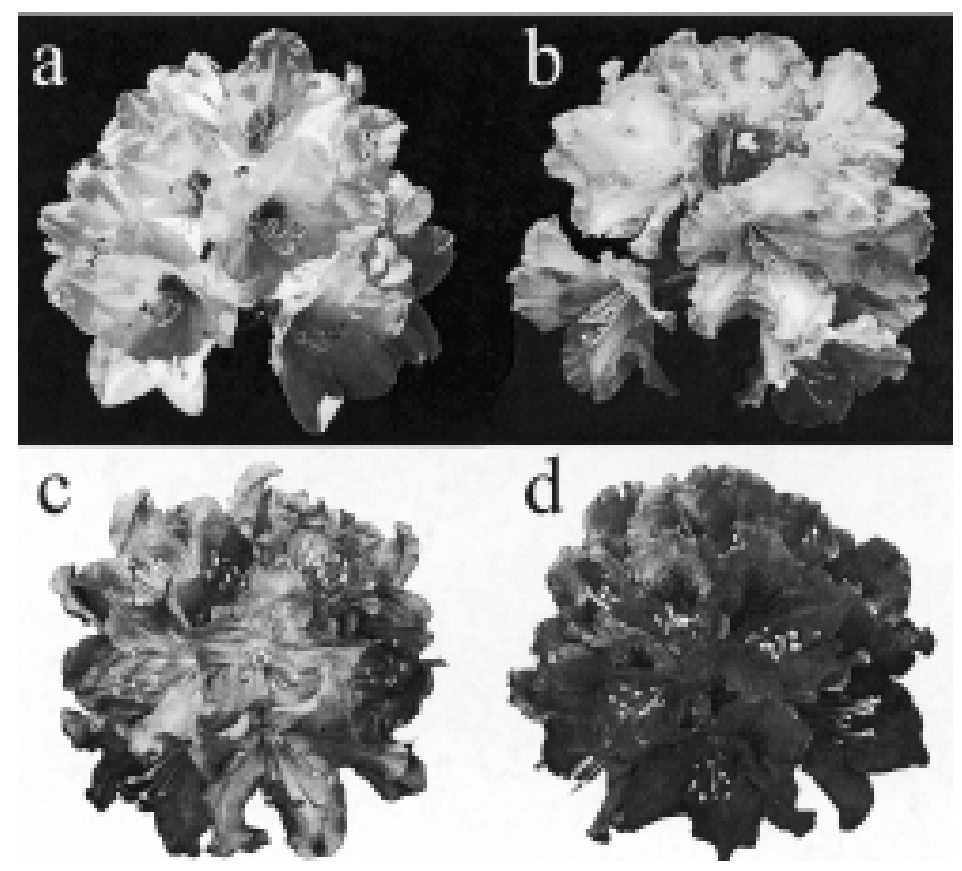

Fig. 5. Flower trusses of (a) Rhododendron 'Buzzer Beater', (b) Rhododendron 'Hoopla', (c) Rhododendron 'Huskymania' and (d) Rhododendron 'Slam Dunk'.

calculated hue angle and chroma for leaves and flowers are given in Table 1.

'Slam Dunk'. Upright, medium-sized rhododendron, $2.1 \mathrm{dm}$ tall $\times 3.1 \mathrm{dm}$ wide after 30 years, and dense with branches broad spreading. Leaves are simple, elliptic, entire, undulate, broadly acute, cuneate, dark green (RHS $147 \mathrm{~A}$ and $139 \mathrm{~A}$ ), and $12 \mathrm{~cm}$ long $\times 5 \mathrm{~cm}$ wide. Trusses are dome-shaped, 10 to $12 \mathrm{~cm}$ tall $\times 15$ to $16 \mathrm{~cm}$ wide, bearing 16 to 20 flowers. Flower buds are grayed-purple (RHS 187A, $187 \mathrm{~B}$ and 183A); calyx is light green, $1 \mathrm{~mm}$ long; corollas (Figure 5D) are broad funnelshaped, 4 to $5 \mathrm{~cm}$ long $\times 7 \mathrm{~cm}$ wide, red-purple (RHS 72A, 71A and 71B), lobes 5 with an undulate fringed margin and the dorsal lobe bearing a wide, $3 \mathrm{~cm}$ blotch or flare that most closely matches grayed-purple (RHS 187A).

'Slam Dunk' exhibits a relatively vigorous growth rate coupled with a dense, rounded habit. Leaves are retained for 3 years and lack indumentum. Plants are floriferous, increasing from moderately to very floriferous with increasing sun exposure at the site. Peak flowering usually occurs in mid-June at Storrs, Conn. The CIELAB values and calculated hue angle and chroma for leaves and flowers are given in Table 1.

\section{Propagation and culture}

All four cultivars can be micropropagated readily using procedures that are effective with other large-leaf rhododendrons. Tissue cultures initiated from actively growing shoot tips were proliferated on Woody Plant medium (Lloyd and McCown, 1980) containing 5 to 10 нм 6- $(\gamma, \gamma$-dimethylallylamino) purine (2iP), $3 \%$ sucrose, $0.1 \%$ phytagel (Sigma Chemical Co., St. Louis), and 0.3\% agar (Sigma) at medium $\mathrm{pH}$ 5.2. Cultures were maintained at $25 \pm 2{ }^{\circ} \mathrm{C}$ under $30 \mu \mathrm{M} \cdot \mathrm{m}^{-2} \cdot \mathrm{s}^{-1}$ light intensity provided by cool-white fluorescent tubes for $16 \mathrm{~h} \cdot$ day $^{-1}$. Microcuttings were well-rooted in 10 to 12 weeks using nonsterile rooting techniques. 'Huskymania' and 'Slam Dunk' proliferate rapidly in vitro, with 'Slam Dunk' producing robust shoots. 'Buzzer Beater' and 'Hoopla' had more modest proliferation rates.

Limited rooting studies at the Univ. of Connecticut indicated that fall-collected shoot cuttings are rooted readily using 8000 $\mathrm{mg} \cdot \mathrm{L}^{-1}$ indole-3-butyric acid (IBA) in talc, 1 sphagnum peat : 1 perlite $(\mathrm{v} / \mathrm{v})$, bottom heat, and intermittent mist. Rooting occurred in $\approx 12$ weeks. Cuttings collected from containerized stock plants rooted at rates of $86 \%$ ('Buzzer Beater'), 70\%('Hoopla'), 77\% (Huskymania), and $92 \%$ ('Slam Dunk').

Marketable 2-gal (7.6-L) plants, with full canopies and flower buds, were produced in 2 years from tissue culture liners. Plants were grown in full sun in 4 aged pine bark : 2 sphagnum peat : 1 sand topdressed each growing season with recommended rates of 8- to 9-month controlled-release fertilizer. Trickle irrigation was used. Overwintering was accomplished in unheated white, polyethylenecovered hoop houses.

'Buzzer Beater', 'Hoopla', 'Huskymania', and 'Slam Dunk' are adaptable to the same cultural conditions as other elepidote rhododendron cultivars and grow best in a moist, well-drained, fertile soil with a $\mathrm{pH}$ of 5.0 to 6.0. Partial shade to full sun is acceptable, but some afternoon shade is advantageous.

Vegetative tissues of all cultivars should be cold-hardy to $-32{ }^{\circ} \mathrm{C}$ based on field and landscape observations and survival. Also, 'Hoopla' and 'Huskymania' flower buds are cold-hardy to $-32{ }^{\circ} \mathrm{C}$. In exposed locations, 'Buzzer Beater' and 'Slam Dunk' flower buds are injured at temperatures below -26 and -29 ${ }^{\circ} \mathrm{C}$, respectively.

\section{Landscape value}

Vigorous, yellow-flowered rhododendrons that can tolerate U.S. Dept. of Agriculture (USDA) hardiness zones 4 or 5 have not been available to those gardening or landscaping in these regions. 'Buzzer Beater' is a light yellowflowered cultivar that exhibits good plant and flower bud hardiness coupled with excellent landscape vigor. Bicolored flowers are just as unusual as yellow flowers on rhododendrons that perform well in regions with cold, harsh winters. The pink and yellow flowers of 'Hoopla' offer a new flower color combination to areas with very cold winters. 'Huskymania' has violet flower buds that open to display purplishblue blossoms with greenish speckling in the upper petal. Another attribute of the flowers is the white stamens that provide a starry effect. This late blooming, very cold-tolerant cultivar adds to the small group of cold-hardy purple to blue-flowered large-leaf rhododendrons. In addition, 'Huskymania' extends the blooming season for this group of landscape plants. 'Slam Dunk' is an improved cultivar for consumers seeking a more compact plant with the same outstanding wine-red flower color of the straggly, sprawling 'Sefton'. The burgundy-red flowers of 'Slam Dunk' possess a large, dark flare, and an unusual color combination for rhododendrons exhibiting reliable cold hardiness in USDA hardiness zones 4 to 5 .

\section{Availability}

'Buzzer Beater', 'Hoopla', 'Huskymania' and 'Slam Dunk' are not patented, but a $\$ 0.10$ per plant voluntary royalty is requested to help support woody plant improvement efforts at the Univ. of Connecticut. Rooted cuttings or micropropagated plants were distributed to cooperating wholesale nurseries for stock increase. Furthermore, shoot proliferating tissue cultures were distributed to some micropropagators. A list of nurseries and micropropagators offering these plants can be provided. Requests for this information should be addressed to Mark Brand.

\section{Literature Cited}

Brand, M.H. and G.A.L. Mehlquist. 1992. Rhododendron 'Firestorm' and 'White Peter'. HortScience 27:480-481.

Brand, M.H. and G.A.L. Mehlquist. 1993. Rhododendron 'Connecticut Yankee' and 'Wojnar's Purple'. HortScience 28:64-65.

Brickell, C.D. (ed.). 1995. International code of nomenclature for cultivated plants-1995. Intl. Comm. for the Nomenclature of Cultivated Plants, Wimborne, U.K.

Dirr, M.A. 1998. Manual of woody landscape plants. 5 th ed. Stipes, Champaign, Ill.

Lloyd, G. and B. McCown. 1980. Commerciallyfeasible micropropagation of mountain laurel, Kalmia latifolia, by the use of shoot tip culture. Proc. Intl. Plant Prop. Soc. 30:421-427.

Royal Horticultural Society. 1986. Royal Horticultural Society colour chart. Royal Hort. Soc., London.

Seve, P. 1991. New formula for the computation of CIE 1976 hue difference. Color Res. Applications 16:217-218.

U.S. Dept. of Agriculture. 1990. Plant hardiness zone map. Misc. Publ. 1475. U.S. Dept. Agr., Agr. Res. Serv., Wash., D.C. 